\title{
A Case Study of Salami Slicing: Pooled Analyses of Duloxetine for Depression
}

\author{
Glen I. Spielmans Tracey L. Biehn Dustin L. Sawrey \\ Department of Psychology, Metropolitan State University, St. Paul, Minn., USA
}

\section{Key Words}

Duloxetine $\cdot$ Salami slicing, duplicate publication •

Depression $\cdot$ Pooled analysis

\begin{abstract}
Background: Publishing separate, yet very similar pieces of a single dataset across multiple papers is known as 'salami slicing'. This practice may be motivated by researchers wishing to increase their publication counts and by the desire to increase exposure of their findings. 'Salami slicing' may also be used by the drug industry to help widely disseminate positive findings regarding its products. Journal editors across many scientific disciplines have bemoaned such duplicative publications on several occasions. However, little research has been conducted on the frequency of such publication practices, and findings have been inconsistent. No research has investigated whether 'salami slicing' may also occur in publications presenting results from pooled analyses of clinical trials. Methods: We examined the scientific literature on duloxetine as a treatment for depression, examining how data from clinical trials were reported across 43 pooled analyses. Results: The vast majority of pooled analyses (88\%) had at least one author who was employed by the manufacturer of duloxetine. Several pooled analyses based on highly overlapping clinical trials presented efficacy and safety data that did not answer unique research questions, and thus ap-
\end{abstract}

peared to qualify as salami publications. Six clinical trials had their data utilized as part of 20 or more separately published pooled analyses. Conclusions: Such redundant publications add little to scientific understanding and represent a poor use of peer reviewer and editorial resources.

Copyright $\odot 2009$ S. Karger AG, Basel

When clinical trials are conducted, data are typically collected on several variables. Many times, a paper describing outcomes on some of these variables is published, followed by further publications which detail similar outcomes from the same trial. For instance, data on some efficacy measures from a given trial may be presented in one publication, followed by data from other efficacy measures in a separate publication. Data from a clinical trial's safety measures may likewise be divided into multiple overlapping publications. If a clinical trial of an antidepressant concludes that the drug is safe and efficacious, it makes little practical sense to publish separate, but highly similar pieces of the trial's results on multiple

Glen Spielmans has holdings of less than USD 10,000 in a mutual fund (Vanguard Health Care), which invests nearly exclusively in pharmaceutical companies. As of September 30, 2008, 4.86\% of the fund's assets were invested in Eli Lilly, manufacturer of duloxetine.

\section{KARGER}

Fax +41613061234 E-Mail karger@karger.ch www.karger.com
(C) 2009 S. Karger AG, Basel

0033-3190/10/0792-0097\$26.00/0

Accessible online at:

www.karger.com/pps
Glen I. Spielmans, PhD

Metropolitan State University, Department of Psychology

1450 Energy Park Drive

St. Paul, MN 55108 (USA)

Tel. +1 651999 5826, Fax +1 651999 5822, E-Mail glen.spielmans@metrostate.edu 
occasions. Carving a study's data into multiple pieces and publishing these similar pieces individually is known as 'salami slicing' or as publishing 'least publishable units' [1-4].

'Salami slicing' may distort the medical literature, making a drug appear as if it has greater support than it has actually garnered from empirical investigations. A reader who does not look closely may not notice that multiple publications regarding a drug's efficacy and safety are actually based on the same underlying group of research participants. Salami manuscripts may waste the valuable time of peer reviewers. Journal editors from a variety of disciplines have bemoaned the practice of 'salami slicing' [1-6]. In general, salami publications have been linked to the 'publish or perish' environment of academia; however, salami publications are likely used for more than just advancing the careers of academics.

Drug marketers have noted that journal publications are an important factor in drug sales. Putting it bluntly, one memo from Pfizer asked 'What is the purpose of publication?' and replied, in part 'High quality and timely publications optimize our ability to sell Zoloft most ef fectively' [7, p. 18]. An internal Eli Lilly document listed 'new studies, publications, presentations ...' under the heading of 'support the schizophrenia and bipolar franchises worldwide' for its antipsychotic drug olanzapine $[8$, p. 3]. PeerView is a company which provides a variety of services to the drug industry, including '... products that support publication strategy and other commercialization processes for our pharmaceutical and biotech clients ...' [9]. PeerView's CEO, Timothy Bacon, stated that '... most pharma and biotech companies recognize the significant impact that the clear and consistent publication of results will have on subsequent commercialization efforts ...' [10, p. 2].

Salami publications may be included as part of a pharmaceutical firm's publication plan. When supportive and highly similar points about a drug's efficacy and/or safety from a single clinical trial are published in a variety of journals, a wide audience of potential prescribers and key opinion leaders is reached. Thus, in addition to padding the curricula vitae of researchers, salami publications may lead to the results of a successful trial being disseminated across several publications, likely helping to boost product visibility and reinforcing the product's key marketing messages. Because various researchers and clinicians read differing journals, they may not notice that redundant findings are being presented in multiple publications. Empirical research on the prevalence of salami publications is relatively sparse and has found quite disparate results [11-14]. Most research on salami publications has focused on overlapping publications of individual clinical trials. Little attention has been placed on pooled analyses, publications in which data from several clinical trials are pooled into a single, larger dataset. However, pooled analyses also present the potential of salami publications, as similar variables from the same, or highly similar, set of clinical trials could be presented across several pooled analyses.

One prior investigation examined the publications associated with 42 clinical trials which examined antidepressants submitted to the Swedish drug regulatory authority [15]. The authors found 11 pooled analyses in which the trials' data were utilized; in some instances, individual trials contributed data to multiple such pooled analyses. However, their sample of pooled analyses was relatively small and the topics of the pooled analyses were not mentioned, making it difficult to know to what extent the pooled analyses contained redundant data. The present study examined the prevalence of salami publications across pooled analyses in the case of the antidepressant duloxetine for depression, focusing on studies that discussed the safety and efficacy of the drug.

\section{Method}

\section{Search Strategy}

We searched Medline and the Cochrane Registry of Controlled Clinical Trials on October 9, 2007 using the search term 'duloxetine'. Duloxetine was selected as the drug of choice because a literature search for a prior meta-analysis [16] revealed the existence of several pooled analyses regarding the drug's safety and efficacy in depression which seemed to present quite similar data. As our analysis was intended to solely investigate studies which examined the efficacy and safety of duloxetine in the treatment of depression, we excluded papers that did not focus directly on these outcomes. Our search yielded 520 articles, of which 401 were eliminated for the following reasons: studied animals $(n=49)$; primarily described the biological effects (i.e., pharmacokinetics or pharmacodynamics) of duloxetine $(\mathrm{n}=44)$; were not relevant to depression $(n=253)$; were not published in English $(n=23)$; were case studies $(n=25)$ or letters to the editor $(n=7)$.

\section{Analysis}

Two reviewers (G.I.S., T.L.B., or D.L.S.) independently categorized each publication into one of three categories: clinical trial, pooled analysis (or post hoc analysis of a single trial), or narrative review article. All disagreements were resolved through consensus. If a publication reported data from a single study in which depressed participants received duloxetine, it was classified as a clinical trial. A placebo or active medication control was not necessary for inclusion as a clinical trial. Pooled analyses combined 
data from two or more clinical trials and must have reported original statistical analyses. We also categorized articles reporting post hoc analyses from a single trial as pooled analyses. Papers which discussed findings of duloxetine research but conducted no original statistical analyses were considered narrative reviews. As our interest was on the literature that primarily concerned duloxetine, we did not include papers which focused on duloxetine as but one of many treatments. For example, a meta-analysis that examined outcomes of all second-generation antidepressants was not included, as its overall focus was on second-generation antidepressants as a whole, not duloxetine in isolation [17]. However, papers which focused on how duloxetine compared to other treatments were included. In each pooled analysis, we examined which clinical trials contributed data for analysis. Whether each publication had at least one author who was an employee of Eli Lilly (manufacturer of duloxetine) was also tabulated.

Labeling an individual paper as a salami publication is at least somewhat subjective in several aspects. For example, if 7 pooled analyses exist regarding a drug's safety for a particular condition, then various reviewers may differ regarding whether each slice of data merited publication as a stand-alone paper. One reviewer may conclude that the data contained across the 7 publications could have been more efficiently presented in 1 or 2 publications, but another reviewer may differ entirely in his or her assessment. Given the inexact nature of assessing overlapping publications, we opted not to label each included pooled analysis as either a salami publication or as sufficiently original. Rather, we examined the general conclusions of each pooled analysis and noted which underlying clinical trials contributed data to each pooled publication. We then noted areas in which data and conclusions appeared to be redundant.

\section{Results}

We found 30 papers which utilized duloxetine in a clinical trial for the treatment of major depression. In addition, our literature search netted 43 pooled analyses (2 of which were post hoc analyses of a single trial) and 46 review articles. Of the clinical trials, 25 (83\%) had at least one author who was employed by Eli Lilly. Of the 43 pooled analyses, 38 (88\%) had at least 1 Eli Lilly-affiliated author, while 8 (17\%) of the narrative review articles had at least one Eli Lilly author.

While reviewing the clinical trials, we found one instance of duplicate publication. A trial compared the outcomes of untreated depressed patients who initiated duloxetine to depressed patients who switched from their current antidepressant to duloxetine. One paper reported outcomes after 8 weeks of the 12-week trial [18], while a second paper reported outcomes at study endpoint without referencing the other publication [19].

Table 1 shows the authors' conclusions from each pooled analysis along with the topic of analysis. Several pooled analyses authored by Eli Lilly scientists appeared to demonstrate 'salami slicing'. For example, one study [20] compared the safety and efficacy of duloxetine in the treatment of African-Americans to Caucasians. Using data from the same underlying clinical trials, another publication compared duloxetine's efficacy and safety between Hispanics and Caucasians [21]. In both cases, the authors concluded that the racial groups did not differ in a meaningful way in their response to duloxetine. Another pooled analysis compared males and females in terms of safety outcomes [22], and another analysis based on the same underlying patients [23] compared genders in terms of efficacy, with neither analysis finding any notable differences along gender lines. One pooled analysis examined the cardiovascular effects of duloxetine in depressed patients [24] while another such analysis reported on the cardiovascular profile of the drug across various conditions [25]; both concluded that the drug possesses a benign cardiovascular safety profile. Other safety or tolerability concerns were examined in several pooled analyses, many of which were based on a very similar set of underlying trials: body weight [26]; suicidal behaviors and ideation [27]; discontinuation symptoms [28]; treatment-emergent hypomania [29]; sexual functioning [30]; urinary side effects [31], and nausea [32]. Other pooled analyses provided analyses of duloxetine's safety and efficacy in patients aged 55 and over [33] and women aged 40-55 [34]; neither analysis concluded that age moderated the drug's efficacy. Several pooled analyses also examined other factors that may moderate the impact of duloxetine: dose-response relationship [35-37]; level of depression severity as a moderator of efficacy $[38,39]$; characteristics of depressive episode [40], and the presence of melancholic features [41]. These analyses concluded that none of the aforementioned traits, with the exception of drug dosage, influenced patient outcome. Other pooled datasets yielded reports of duloxetine's effects in: treating milder depression [42]; treating depression using number needed to treat as the outcome variable [43]; time course to improvement [44]; onset of action [45], and treating depression with comorbid anxiety symptoms [46]. The analyses examining time course to improvement and onset of action were based on the same 2 underlying clinical trials. In addition, 6 pooled analyses reported analyses based solely on data from 2 clinical trials.

Double-blind clinical trials were easily the most commonly included sources of data in pooled analyses. Table 2 displays the number of occasions in which the 8 most frequently cited clinical trials, all of which were double-blind, were included as part of a pooled analysis. Six trials were included in 20 or more pooled analyses. 
Table 1. Pooled analyses focusing on duloxetine as a treatment for depression

\begin{tabular}{lll}
\hline Study & Focus & $\begin{array}{l}\text { Lilly Trials included } \\
\text { authors? }\end{array}$ \\
\hline
\end{tabular}

Acharya et al. Suicidal behaviors and Yes_ Does not cite trials 'We found no evidence of an increased risk of suicidal behaviors or idea-
ideation individually; claims all tion during treatment with duloxetine compared with placebo in MDD 27 phase II and III trials patients. HAMD item-3 suicidality scores had more improvement and less were included worsening of suicidal ideation with duloxetine than placebo.' (p. 587)

\begin{tabular}{|c|c|c|c|c|}
\hline $\begin{array}{l}\text { Bailey et al. } \\
{[20]}\end{array}$ & $\begin{array}{l}\text { Efficacy and tolerability: } \\
\text { African-American vs. } \\
\text { White }\end{array}$ & Yes & {$[50-54,80,81]$} & $\begin{array}{l}\text { '... no convincing evidence was found to suggest that the overall safety } \\
\text { and tolerability profile or the efficacy profile for duloxetine in this cohort } \\
\text { of African-American patients differed from that observed in a comparator } \\
\text { group of Caucasian patients.' (p. } 437 \text { ) }\end{array}$ \\
\hline
\end{tabular}

Ballesteros et al. Response, remission No $\quad[50,51,53,56,57] \quad$ 'At the moment, we sincerely think more research is needed to clarify the [55] additional trial not cited current evidence regarding the comparative efficacy of duloxetine across different dose ranges.' (p. 221)

\begin{tabular}{llll}
\hline $\begin{array}{l}\text { Bech et al. } \\
{[35]}\end{array}$ & $\begin{array}{l}\text { Dose-response } \\
\text { relationship }\end{array}$ & Yes $\quad[50,51,53,56,57,81]$ & $\begin{array}{l}\text { 'Findings support that duloxetine } 60 \text { mg daily is the best effective dose.' } \\
\text { (p. 273) }\end{array}$
\end{tabular}

Brannan et al. Onset of action Yes $\quad[51,53] \quad$ 'In this study, duloxetine-treated patients demonstrated clinically

[45] $\quad[51,53]$
meaningful improvements within the first weeks of treatment. Approximately $35 \%$ of the total baseline-to-endpoint improvement for duloxetine-treated patients occurred in the first week of treatment, while approximately $50 \%$ of the total improvement had been achieved following 2 weeks of therapy.' (p. 171)

\begin{tabular}{llll}
\hline $\begin{array}{l}\text { Burt et al. } \\
{[34]}\end{array}$ & Women aged $40-55$ & Yes & {$[51,53]$} \\
& & & \\
\hline Cookson et al. & $\begin{array}{l}\text { Efficacy with number } \\
\text { needed to treat as DV }\end{array}$ & Yes & $\begin{array}{l}{[50,51,53,54,56-58,} \\
80,81]\end{array}$ \\
& & &
\end{tabular}

'The magnitude of duloxetine's treatment effect in women ages 40-55 was similar to that observed in younger (age <40 years) and older (age > 55 years) female patients.' (p. 345)

'The [number needed to treat] for several measures of efficacy including remission consistently demonstrated the treatments benefits of duloxetine as well as of fluoxetine and paroxetine compared to placebo.' (p. 267)

\begin{tabular}{lll}
\hline $\begin{array}{l}\text { Delgado et al. } \\
\text { [30] }\end{array}$ & $\begin{array}{l}\text { Sexual functioning } \\
\text { compared to paroxetine }\end{array}$ & Yes \\
and placebo
\end{tabular}

‘... patients receiving duloxetine ( $40-120 \mathrm{mg} /$ day) or paroxetine $(20 \mathrm{mg} /$ day) had a significantly higher incidence of acute treatment-emergent sexual dysfunction when compared with placebo patients. However, the incidence of acute treatment-emergent dysfunction for duloxetine was significantly lower than that observed for paroxetine.' (p. 686)

\begin{tabular}{|c|c|c|c|c|}
\hline $\begin{array}{l}\text { Dunner et al., } \\
2003 \text { [46] }\end{array}$ & $\begin{array}{l}\text { Treatment of anxiety } \\
\text { symptoms in depression }\end{array}$ & Yes & {$[50,51,53,54]$} & $\begin{array}{l}\text { 'In these studies, duloxetine provided rapid relief of anxiety symptoms } \\
\text { associated with depression that lasted throughout the acute treatment } \\
\text { period.' (p. 61) }\end{array}$ \\
\hline $\begin{array}{l}\text { Dunner et al. } \\
\text { [29] }\end{array}$ & $\begin{array}{l}\text { Treatment-emergent } \\
\text { hypomania }\end{array}$ & Yes & $\begin{array}{l}\text { Eight trials; no } \\
\text { individual trials cited }\end{array}$ & $\begin{array}{l}\text { 'Duloxetine was associated with a low incidence of treatment-emergent } \\
\text { hypomania, mania, of hypomanic-like symptoms in patients with major } \\
\text { depressive disorder.' (p. 115) }\end{array}$ \\
\hline $\begin{array}{l}\text { Eckert and } \\
\text { Lançon [59] }\end{array}$ & $\begin{array}{l}\text { Duloxetine compared } \\
\text { to venlafaxine and } \\
\text { fluoxetine }\end{array}$ & No & $\begin{array}{l}22 \text { fluoxetine trials } \\
9 \text { duloxetine trials } \\
8 \text { venlafaxine trials } \\
{[50-54,57,80,81]} \\
\text { one trial not in our } \\
\text { database }\end{array}$ & $\begin{array}{l}\text { 'Fluoxetine was not significantly different in either tolerability or efficacy } \\
\text { when compared with duloxetine. Venlafaxine was significantly superior } \\
\text { to duloxetine in all analyses except dropout rate. In the absence of relevant } \\
\text { data from head-to-head comparison trials, results suggest that venlafaxine } \\
\text { is superior compared with duloxetine and that duloxetine does not } \\
\text { differentiate from fluoxetine.' (p. 1) }\end{array}$ \\
\hline $\begin{array}{l}\text { Fava et al. } \\
{[60]}\end{array}$ & $\begin{array}{l}\text { Efficacy for painful } \\
\text { physical symptoms in } \\
\text { depression }\end{array}$ & Yes & {$[51,53]$} & $\begin{array}{l}\text { 'Treatment with duloxetine, } 60 \mathrm{mg} \text { q.d., significantly reduced pain } \\
\text { compared with placebo. Improvements in pain severity were attributable } \\
\text { equally to the direct effect of duloxetine and to associated changes in } \\
\text { depression severity.' (p. 521) }\end{array}$ \\
\hline $\begin{array}{l}\text { Fava } \\
\text { et al. [61] }\end{array}$ & $\begin{array}{l}\text { Anxious vs. non-anxious } \\
\text { depression }\end{array}$ & Yes & [19] & $\begin{array}{l}\text { 'Duloxetine's efficacy in anxious depression was somewhat superior to } \\
\text { non-anxious depression; tolerability was comparable between groups.' } \\
\text { (p. 187) }\end{array}$ \\
\hline $\begin{array}{l}\text { Gahimer } \\
\text { et al. [62] }\end{array}$ & $\begin{array}{l}\text { Safety analysis across } \\
\text { various indications }\end{array}$ & Yes & $\begin{array}{l}64 \text { trials; no individual } \\
\text { trials cited }\end{array}$ & $\begin{array}{l}\text { 'The safety profile for the molecule from the overall duloxetine exposures } \\
\text { integrated safety database suggests that benign and common pharmaco- } \\
\text { logic side effects occur with duloxetine treatment.' (p. 175) }\end{array}$ \\
\hline
\end{tabular}


Table 1 (continued)

\begin{tabular}{lll}
\hline Study Focus & $\begin{array}{l}\text { Lilly Trials included } \\
\text { authors? }\end{array}$ \\
\hline
\end{tabular}

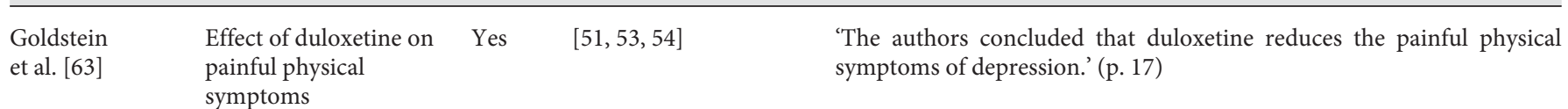

\begin{tabular}{|c|c|c|c|c|}
\hline $\begin{array}{l}\text { Greist } \\
\text { et al. [32] }\end{array}$ & $\begin{array}{l}\text { Incidence and onset of } \\
\text { nausea }\end{array}$ & Yes & $\begin{array}{l}{[50,51,53,54,56,57,} \\
80,81]\end{array}$ & $\begin{array}{l}\text { 'Duloxetine induced mild to moderate nausea in a subset of patients with } \\
\text { MDD during treatment initiation. Nausea resolved rapidly with contin- } \\
\text { ued treatment. The incidence of duloxetine-induced nausea resembled } \\
\text { that produced by paroxetine and fluoxetine.' (p. 1446) }\end{array}$ \\
\hline
\end{tabular}

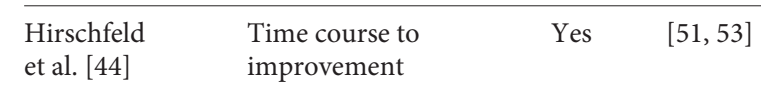

'Clinically meaningful response to duloxetine therapy was most rapid for some of the emotional and painful physical symptoms of depression (week 1), with symptoms of retardation and hypochondriasis responding within 2 to 3 weeks, respectively. Slower responses (5-9 weeks) were achieved for sleep, genital, and nonpainful somatic symptoms.' (p. 176)

\begin{tabular}{llll}
$\begin{array}{l}\text { Hudson } \\
\text { et al. [64] }\end{array}$ & Safety and tolerability $\quad$ Yes & $\begin{array}{l}{[50,51,53,54,56,57,} \\
80,81]\end{array}$ & $\begin{array}{l}\text { 'The results are consistent with those obtained previously from smaller } \\
\text { pooled data sets, and suggest that duloxetine is safe and well tolerated in } \\
\text { patients with MDD.' (p. 327) }\end{array}$ \\
\hline
\end{tabular}

\begin{tabular}{|c|c|c|c|c|}
\hline $\begin{array}{l}\text { Khan and } \\
\text { Schwartz } \\
{[65]}\end{array}$ & Efficacy and suicidality & No & $\begin{array}{l}\text { Six duloxetine } \\
\text { Four escitalopram } \\
\text { Unclear which trials } \\
\text { were included }\end{array}$ & $\begin{array}{l}\text { 'Suicide and suicide attempt risk varied considerably ... We also noted } \\
\text { similar magnitude of response to placebo and antidepressants among the } \\
\text { three studies [referencing two prior publications and the current analysis].' } \\
\text { (p. 31) }\end{array}$ \\
\hline
\end{tabular}

\begin{tabular}{llll}
\hline $\begin{array}{l}\text { Kornstein } \\
\text { et al. [23] }\end{array}$ & Male vs. female: efficacy & Yes & {$[50-54,80,81]$}
\end{tabular} \begin{tabular}{l}
$\begin{array}{l}\text { 'In this analysis of pooled data, the efficacy of duloxetine did not differ } \\
\text { significantly in male and female patients.' (p. } 761)\end{array}$ \\
\hline
\end{tabular}

\begin{tabular}{|c|c|c|c|c|}
\hline $\begin{array}{l}\text { Lewis-Fernandez } \\
\text { et al. [21] }\end{array}$ & Hispanic vs. Caucasian & Yes & {$[50-54,80,81]$} & $\begin{array}{l}\text { 'In this analysis of pooled data, no evidence for a differential effect of } \\
\text { duloxetine in Hispanic and majority Caucasian patients was found in }\end{array}$ \\
\hline
\end{tabular}
et al. [21] efficacy or safety outcomes.' (p. 1379)

\begin{tabular}{|c|c|c|c|c|}
\hline $\begin{array}{l}\text { Mallinckrodt } \\
\text { et al. [66] }\end{array}$ & Efficacy and safety & Yes & {$[50,51,53,54,80,81]$} & $\begin{array}{l}\text { 'In these studies, duloxetine was safe and effective in the treatment of both } \\
\text { emotional and physical symptoms of MDD. Based on dose assessments, } 60 \\
\text { mg q.d. appears to be the optimum starting and therapeutic dose.' (p. 19) }\end{array}$ \\
\hline $\begin{array}{l}\text { Mallinckrodt } \\
\text { et al. [67] }\end{array}$ & $\begin{array}{l}\text { Assessment of efficacy } \\
\text { using MMRM vs. LOCF } \\
\text { methods }\end{array}$ & Yes & $\begin{array}{l}{[50,51,53,54,56,57,} \\
80,81]\end{array}$ & $\begin{array}{l}\text { 'Empirical research has clearly demonstrated the theoretical advantages } \\
\text { of MMRM over LOCF-ANOVA. However, interpretations regarding the } \\
\text { efficacy of duloxetine in MDD were unaffected by the choice of analytic } \\
\text { technique.' (p. 1) }\end{array}$ \\
\hline
\end{tabular}

\begin{tabular}{|c|c|c|c|c|}
\hline $\begin{array}{l}\text { Mallinckrodt } \\
\text { et al. [41] }\end{array}$ & $\begin{array}{l}\text { Depression with and } \\
\text { without melancholic } \\
\text { features }\end{array}$ & Yes & $\begin{array}{l}{[50,51,53,54,56,57} \\
80,81] \\
\text { Two others referenced }\end{array}$ & $\begin{array}{l}\text { 'In the analysis of pooled data, the efficacy of duloxetine in patients with } \\
\text { melancholic features did not differ significantly from that observed in } \\
\text { non-melancholic patients.' (p. 1) }\end{array}$ \\
\hline
\end{tabular}
as part of New Drug Application reviewed by FDA for depression

\begin{tabular}{|c|c|c|c|c|}
\hline $\begin{array}{l}\text { Mallinckrodt } \\
\text { et al. [37] }\end{array}$ & $\begin{array}{l}\text { Efficacy and safety of } 40 \\
\text { mg and } 60 \mathrm{mg} \text { doses }\end{array}$ & Yes & {$[50,51,53,81]$} & $\begin{array}{l}\text { 'Duloxetine provides safe and effective acute phase treatment of MDD at } \\
\text { doses of } 40 \mathrm{mg}-60 \mathrm{mg} / \text { day. Compared with placebo, the } 60 \mathrm{mg} \text { QD dose } \\
\text { was more consistently effective than the } 20 \mathrm{mg} \text { BID dose. However, the } \\
\text { incidence of certain treatment-emergent adverse events is likely to be } \\
\text { lower at the } 40 \mathrm{mg} \text { dose.' (p. 337) }\end{array}$ \\
\hline $\begin{array}{l}\text { Mallinckrodt } \\
\text { et al. [68] }\end{array}$ & $\begin{array}{l}\text { Comparison of MMRM } \\
\text { vs. LOCF methods }\end{array}$ & Yes & $\begin{array}{l}{[50,51,53,54,56,57} \\
69,70,80,81]\end{array}$ & $\begin{array}{l}\text { 'Researchers may be able to take advantage of these easy-to-implement } \\
\text { methods while we wait for further improvement in other areas.' (p. 101) }\end{array}$ \\
\hline $\begin{array}{l}\text { Nelson } \\
\text { et al. [33] }\end{array}$ & Age $\geq 55$ & Yes & {$[51,53]$} & $\begin{array}{l}\text { '... duloxetine } 60 \mathrm{mg} / \text { day was an efficacious treatment for MDD and } \\
\text { also alleviated pain symptoms in depression patients age } 55 \text { and older.' } \\
\text { (p. 227) }\end{array}$ \\
\hline $\begin{array}{l}\text { Nelson } \\
\text { et al. [71] }\end{array}$ & $\begin{array}{l}\text { Safety and tolerability } \\
\text { compared with } \\
\text { paroxetine and placebo }\end{array}$ & Yes & {$[50,56,57,81]$} & $\begin{array}{l}\text { 'Duloxetine is safe and well tolerated in patients with MDD, with safety } \\
\text { and tolerability comparable to that of paroxetine.' (p. 212) }\end{array}$ \\
\hline $\begin{array}{l}\text { Perahia } \\
\text { et al. [28] }\end{array}$ & $\begin{array}{l}\text { Discontinuation } \\
\text { symptoms }\end{array}$ & Yes & $\begin{array}{l}{[50,51,53,54,56,57} \\
78,80,81]\end{array}$ & $\begin{array}{l}\text { 'Abrupt discontinuation of duloxetine is associated with a [discontinua- } \\
\text { tion-emergent adverse event] profile similar to that seen with other } \\
\text { selective serotonin reuptake inhibitor (SSRI) and selective serotonin and } \\
\text { norepinephrine reuptake inhibitor (SNRI) antidepressants.' (p. 207) }\end{array}$ \\
\hline
\end{tabular}


Table 1 (continued)

\begin{tabular}{llll}
\hline Study & Focus & $\begin{array}{l}\text { Lilly } \\
\text { authors? }\end{array}$ & Trials included \\
\hline $\begin{array}{l}\text { Perahia } \\
\text { et al. }[40]\end{array}$ & $\begin{array}{l}\text { Characteristics of } \\
\text { depression }\end{array}$ & Yes & $\begin{array}{l}{[50,51,53,54,56,57,} \\
78,80,81]\end{array}$ \\
& & &
\end{tabular}

Conclusion

\begin{tabular}{llll} 
& & & \\
\hline $\begin{array}{l}\text { Perahia } \\
\text { et al. [42] }\end{array}$ & $\begin{array}{l}\text { Treatment of milder } \\
\text { major depression }\end{array}$ & Yes & {$[51,53]$} \\
\hline $\begin{array}{l}\text { Perahia } \\
\text { et al. [72] }\end{array}$ & $\begin{array}{l}\text { Depression: risk-benefit } \\
\text { profile compared to } \\
\text { venlafaxine }\end{array}$ & Yes & $\begin{array}{l}\text { Two trials published } \\
\text { after end of our search } \\
\text { period }\end{array}$ \\
\hline $\begin{array}{l}\text { Pritchett } \\
\text { et al. [36] }\end{array}$ & $\begin{array}{l}\text { Using effect size to } \\
\text { determine optimal } \\
\text { duloxetine dose }\end{array}$ & Yes & {$[50,51,53,56,57,81]$} \\
\hline $\begin{array}{l}\text { Raskin } \\
\text { et al. [73] }\end{array}$ & $\begin{array}{l}\text { Post-hoc analysis of } \\
\text { single trial }\end{array}$ & Yes & {$[69]$} \\
\hline $\begin{array}{l}\text { Shelton } \\
\text { et al. [39] }\end{array}$ & $\begin{array}{l}\text { Level of depression } \\
\text { severity as moderator of } \\
\text { efficacy }\end{array}$ & Yes & {$[51,53,69,74]$} \\
\hline $\begin{array}{l}\text { Shelton } \\
\text { et al. [38] }\end{array}$ & $\begin{array}{l}\text { Level of depression } \\
\text { severity as moderator of } \\
\text { efficacy }\end{array}$ & Yes & {$[50,51,53,54,56,57$,} \\
& & $69,80,81]$
\end{tabular}

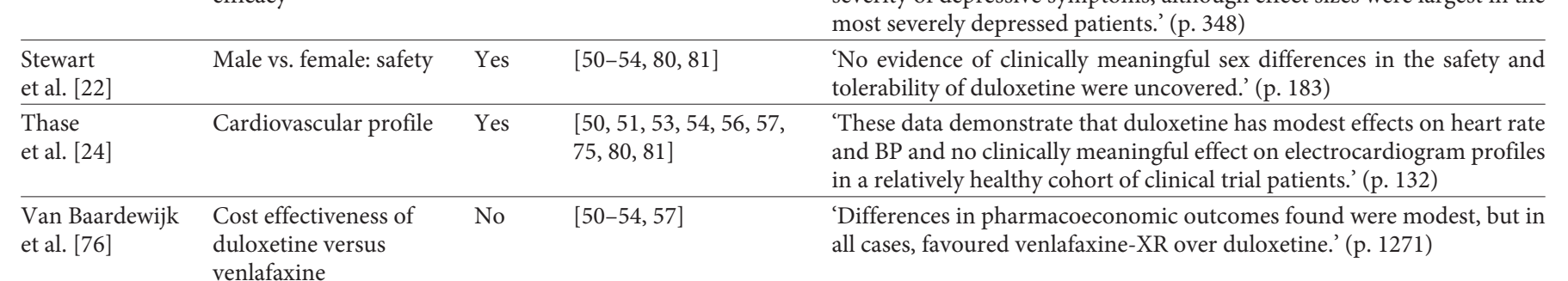

Viktrup Urinary side effects $\quad$ Yes $\quad$ Eight depression trials; 'Duloxetine treatment in women and men with depression and in women
incontinence trials; no individual studies cited

\begin{tabular}{|c|c|c|c|c|}
\hline & & & & \\
\hline $\begin{array}{l}\text { Vis } \\
\text { et al. [77] }\end{array}$ & $\begin{array}{l}\text { Meta-analysis of indirect } \\
\text { comparisons between } \\
\text { duloxetine and } \\
\text { venlafaxine }\end{array}$ & No & {$[50-54,57]$} & $\begin{array}{l}\text { 'Venlafaxine-XR tends to have a favorable trend in remission and response } \\
\text { rates compared with duloxetine. However, dropout rates and adverse } \\
\text { events did not differ. A direct comparison is warranted to confirm this } \\
\text { tendency.' (p. 1798) }\end{array}$ \\
\hline $\begin{array}{l}\text { Wernicke } \\
\text { et al. [25] }\end{array}$ & $\begin{array}{l}\text { Cardiovascular safety } \\
\text { profile across several } \\
\text { conditions }\end{array}$ & Yes & $\begin{array}{l}42 \text { trials (including } \\
\text { trials for other } \\
\text { conditions) } \\
{[50-54,56,57,69,74}\end{array}$ & $\begin{array}{l}\text { 'Overall, the findings presented here support our conclusions that use of } \\
\text { duloxetine does not appear to be associated with significant cardiovascular } \\
\text { risks in patients with conditions for which the drug has been approved or } \\
\text { studied.' (p. 438) }\end{array}$ \\
\hline
\end{tabular}

\begin{tabular}{llll}
\hline Wise & Effect on body weight & Yes & {$[51]$} \\
et al. [26] & & \\
& & & $78-81]$
\end{tabular}

'Duloxetine-treated patients experienced weight loss after short-term treatment, followed by modest weight gain on longer-term treatment. The size of the weight changes observed suggests that the antidepressant duloxetine has minimal effects on weight for the majority of patients.' (p. 269) 
Table 2. Trials most frequently cited in pooled analyses

\begin{tabular}{|c|c|}
\hline Study & $\begin{array}{l}\text { Number of pooled analyses } \\
\text { including data from trial }\end{array}$ \\
\hline Detke et al. [53] & 33 \\
\hline Detke et al. [51] & 33 \\
\hline Goldstein et al. [50] & 27 \\
\hline Eli Lilly Study 4091a [80] ${ }^{1}$ & 23 \\
\hline Goldstein et al. [54] & 22 \\
\hline Detke et al. [57] & 20 \\
\hline Eli Lilly Study 3327b [81] ${ }^{1}$ & 18 \\
\hline Perahia et al. [56] & 17 \\
\hline
\end{tabular}

\footnotetext{
${ }^{1}$ Indicates study that was not published as a standalone article. Data from these trials are available from the Eli Lilly online clinical trial registry.
}

\section{Discussion}

Our findings suggest that many pooled analyses regarding the efficacy and safety of duloxetine have substantial redundancy. In many instances, it was difficult to ascertain how such salami publications were making substantial contributions to the scientific literature. Several clinical trials were included in over 20 pooled analyses.

We do not claim that the scientific questions examined in the pooled analyses lacked legitimate scientific importance. For example, the potential interaction of gender and race with treatment response is certainly a topic of interest. However, given that Latinos, Blacks, and Whites all tended to respond similarly to duloxetine and that gender also did not moderate outcome, it seems that such data could easily have been presented in a single publication rather than in 3 published pooled analyses. Likewise, data on safety outcomes were sliced into several pieces. It is unclear how an individual publication is needed to report data separately for safety outcomes such as nausea, sexual side effects, urinary side effects, and several others. Multiple publications based on similar data which conclude that duloxetine is effective for mild depression, melancholic depression, and across differing lengths of depressive episodes likewise seem redundant. A much smaller number of publications could likely have communicated such data just as clearly. Further, the sample size of some pooled analyses was rather small; 6 pooled analyses included only data from 2 clinical trials. It is likely that exceedingly few meta-analyses have been published based on only 2 tri- als, raising the question of why pooled analyses based on only 2 trials warrant publication in the absence of novel scientific data.

A limitation of the current investigation is that the inappropriateness of 'salami slicing' is not universally agreed upon. What may be considered redundant information by some may be considered an important scientific contribution by others. Thus, we acknowledge that different evaluators may draw different conclusions regarding whether these publications were appropriate. However, we believe that publishing similar outcomes from the same dataset of publications on several occasions better serves the curricula vitae of researchers and, potentially, goals of drug marketers, than it does science and patient care.

Outside of Melander et al. [15], we are aware of no other investigation which has examined the prevalence of redundant pooled analyses. We only included publications on a single drug and focused on only the literature related to one of its multiple indications. It is certainly possible that pooled analyses regarding duloxetine are not representative of the broader scientific literature. Indeed, given our limited focus, it is likely inappropriate to generalize that pooled analyses containing redundant data are widely spread in the psychiatric or wider medical literature. We have simply demonstrated that in the instance of duloxetine in the treatment of depression, 'salami slicing' appears to have taken place with substantial frequency via pooled analyses.

Writings from the drug industry indicate that medical journal publications, rather than just communicating scientific findings, are an important part of the drug marketing process. As written in a medical marketing trade publication, 'the goal of strategic publication planning is to accelerate the adoption of a new chemical entity and, by doing so, accelerate uptake after it enters the market' [47, p. 41]. The same author noted that a good strategic publication plan supports a product's 'selling platform' [47, p. 41]. Documents from Pfizer and Eli Lilly indicate similar views, that journal publications are linked to product sales $[7,8]$.

Journal editors, peer reviewers, and researchers should be aware that salami publication wastes valuable resources of editors, reviewers, and journals [1-6]. Further, salami publications may be more representative of propaganda than of actual contributions to science [48]. The fact that such redundant publications have appeared in a wide variety of medical journals raises questions about the quality of peer review and what passes for 'original' science. A recent editorial raised concerns that the medi- 
cal literature has a 'bias in favour of valuable commercial content as opposed to tough-minded critical analysis' [49, p. 199]; our findings lend credence to such views. Greater vigilance on the part of reviewers and editors may help to curb such publication practices, but the ultimate responsibility lies with authors, who should understand that 'salami science' does little to advance either science or patient care.

\section{References}

1 Brochard L, Brun-Buisson C: Salami publication: a frequent practice affecting readers' confidence. Intensive Care Med 2007;33: 212-213.

2 Hoit JD: Salami science. Am J Speech Lang Pathol 2007;16:94.

3 Johnson C: Repetitive, duplicate, and redundant publications: a review for authors and readers. J Manipulative Physiol Ther 2006; 29:505-509.

4 Baggs JG: Issues and rules for authors concerning authorship versus acknowledgements, dual publication, self plagiarism, and salami publishing. Res Nurs Health 2008;31: 295-297.

5 Britton J, Knox AJ: Duplicate publication, redundant publication, and disclosure of closely related publications. Thorax 1999;54:378.

6 Norman I, Griffiths P: Duplicate publication and 'salami slicing': ethical issues and practical solutions. Int J Nurs Stud 2008;45:12571260.

7 Moffatt B, Elliott C: Ghost marketing: pharmaceutical companies and ghostwritten journal articles. Perspect Biol Med 2007;50: $18-31$

8 Eli Lilly: 2001 integrated product plan: Zyprexa product team. http://www.furiousseasons.com/zyprexa\%20documents / ZY201249534.pdf.

9 PeerView, Inc: About PeerView, Inc. 2005. http://epeerview.com/general/about.html.

10 Villarroel EP: Master plan: the making of a successful publication strategy. Pharmavoice 2007;3:1-5.

11 Bailey BJ: Duplicate publication in the field of otolaryngology-head and neck surgery. Otolaryngol Head Neck Surg 2002;126:211-216.

12 Durani P: Duplicate publications: redundancy in plastic surgery literature. J Plast Reconstr Aesthet Surg 2006;59:975-977.

13 Schein M, Paladugu R: Redundant surgical publications: tip of the iceberg? Surgery 2001;129:655-661.

14 von Elm E, Poglia G, Walder B, Tramèr MR: Different patterns of duplicate publication: an analysis of articles used in systematic reviews. JAMA 2004;291:974-980.

15 Melander H, Ahlqvist-Rastad J, Meijer G, Beermann B: Evidence b(i)ased medicine Selective reporting from studies sponsored by pharmaceutical industry: review of studies in new drug applications. BMJ 2003;326: 1171-1173.
16 Spielmans GI: Duloxetine does not relieve painful physical symptoms in depression: a meta-analysis. Psychother Psychosom 2008; 77:12-16.

17 Hansen RA, Gartlehner G, Lohr KN, Gaynes BN, Carey TS: Efficacy and safety of secondgeneration antidepressants in the treatment of major depressive disorder. Ann Intern Med 2005; 143:415-426.

18 Wohlreich MM, Mallinckrodt $\mathrm{CH}$, Watkin JG, Wilson MG, Greist JH, Delgado PL, Fava M: Immediate switching of antidepressant therapy: results from a clinical trial of duloxetine. Ann Clin Psychiatry 2005;17:259268.

19 Wohlreich MM, Martinez JM, Mallinckrodt $\mathrm{CH}$, Prakash A, Watkin JG, Fava M: An open-label study of duloxetine for the treatment of major depressive disorder: comparison of switching versus initiating treatment approaches. J Clin Psychopharmacol 2005; 25:552-560.

20 Bailey RK, Mallinckrodt $\mathrm{CH}$, Wohlreich MM, Watkin JG, Plewes JM: Duloxetine in the treatment of major depressive disorder: comparisons of safety and efficacy. J Natl Med Assoc 2006;98:437-447.

21 Lewis-Fernández R, Blanco C, Mallinckrodt $\mathrm{CH}$, Wohlreich MM, Watkin JG, Plewes JM: Duloxetine in the treatment of major depressive disorder: comparisons of safety and efficacy in US Hispanic and majority Caucasian patients. J Clin Psychiatry 2006;67: 1379-1390.

22 Stewart DE, Wohlreich MM, Mallinckrodt $\mathrm{CH}$, Watkin JG, Kornstein SG: Duloxetine in the treatment of major depressive disorder: comparisons of safety and tolerability in male and female patients. J Affect Disord 2006;94:183-189.

23 Kornstein SG, Wohlreich MM, Mallinckrod CH, Watkin JG, Stewart DE: Duloxetine efficacy for major depressive disorder in male versus female patients: data from 7 randomized, double-blind, placebo-controlled trials. J Clin Psychiatry 2006;67:761-770.

24 Thase ME, Tran PV, Wiltse C, Pangallo BA, Mallinckrodt C, Detke MJ: Cardiovascular profile of duloxetine, a dual reuptake inhibitor of serotonin and norepinephrine. J Clin Psychopharmacol 2005;25:132-140.
25 Wernicke J, Lledó A, Raskin J, Kajdasz DK, Wang F: An evaluation of the cardiovascular safety profile of duloxetine: findings from 42 placebo-controlled studies. Drug Saf 2007; 30:437-455

26 Wise TN, Perahia DG, Pangallo BA, Losin WG, Wiltse CG: Effects of the antidepressant duloxetine on body weight: analyses of 10 clinical studies. Prim Care Companion J Clin Psychiatry 2006;8:269-278.

27 Acharya N, Rosen AS, Polzer JP, D'Souza DN, Perahia DG, Cavazzoni PA, Baldessarini RJ: Duloxetine: meta-analyses of suicidal behaviors and ideation in clinical trials for major depressive disorder. J Clin Psychopharmacol 2006;26:587-594.

28 Perahia DG, Kajdasz DK, Desaiah D, Haddad PM: Symptoms following abrupt discontinuation of duloxetine treatment in patients with major depressive disorder. J Affect Disord 2005;89:207-212.

29 Dunner DL, D’Souza DN, Kajdasz DK, Detke MJ, Russell JM: Is treatment-associated hypomania rare with duloxetine: secondary analysis of controlled trials in non-bipolar depression. J Affect Disord 2005;87:115119.

30 Delgado PL, Brannan SK, Mallinckrodt CH, Tran PV, McNamara RK, Wang F, Watkin JG, Detke MJ: Sexual functioning assessed in 4 double-blind placebo- and paroxetinecontrolled trials of duloxetine for major depressive disorder. J Clin Psychiatry 2005;66: 686-692.

31 Viktrup L, Pangallo BA, Detke MJ, Zinner NR: Urinary side effects of duloxetine in the treatment of depression and stress urinary incontinence. Prim Care Companion J Clin Psychiatry 2004;6:65-73.

32 Greist J, McNamara RK, Mallinckrodt $\mathrm{CH}$, Rayamajhi JN, Raskin J: Incidence and duration of antidepressant-induced nausea: duloxetine compared with paroxetine and fluoxetine. Clin Ther 2004;26:1446-1455.

33 Nelson JC, Wohlreich MM, Mallinckrodt CH, Detke MJ, Watkin JG, Watkin JG, Kennedy JS: Duloxetine for the treatment of major depressive disorder in older patients. Am J Geriatr Psychiatry 2005;13:227-235.

34 Burt VK, Wohlreich MM, Mallinckrodt CH, Detke MJ, Watkin JG, Stewart DE: Duloxetine for the treatment of major depressive disorder in women ages 40 to 55 years. Psychosomatics 2005;46:345-354 
35 Bech P, Kajdasz DK, Porsdal V: Dose-response relationship of duloxetine in placebocontrolled clinical trials in patients with majordepressivedisorder. Psychopharmacology (Berl) 2006;188:273-280.

36 Pritchett YL, Marciniak MD, Corey-Lisle PK, Berzon RA, Desaiah D, Detke MJ: Use of effect size to determine optimal dose of duloxetine in major depressive disorder. J Psychiatr Res 2007;41:311-318.

37 Mallinckrodt CH, Prakash A, Andorn AC, Watkin JG, Wohlreich MM: Duloxetine for the treatment of major depressive disorder: a closer look at efficacy and safety data across the approved dose range. J Psychiatr Res 2006; $40: 337-348$

38 Shelton RC, Andorn AC, Mallinckrodt CH, Wohlreich MM, Raskin J, Watkin JG, Detke MJ: Evidence for the efficacy of duloxetine in treating mild, moderate, and severe depression. Int Clin Psychopharmacol 2007;22: 348-355.

39 Shelton RC, Prakash A, Mallinckrodt CH, Wohlreich MM, Raskin J, Robinson MJ, Detke MJ: Patterns of depressive symptom response in duloxetine-treated outpatients with mild, moderate or more severe depression. Int J Clin Pract 2007;618:1337-1348.

40 Perahia DG, Kajdasz DK, Royer MG, Walker DJ, Raskin J: Duloxetine in the treatment of major depressive disorder: an assessment of the relationship between outcomes and episode characteristics. Int Clin Psychopharmacol 2006;21:285-295.

41 Mallinckrodt CH, Watkin JG, Liu C, Wohlreich MM, Raskin J: Duloxetine in the treatment of major depressive disorder: a comparison of efficacy in patients with and without melancholic features. BMC Psychiatry 2005;5:1.

42 Perahia DG, Kajdasz DK, Walker DJ, Raskin J, Tylee A: Duloxetine $60 \mathrm{mg}$ once daily in the treatment of milder major depressive disorder. Int J Clin Pract 2006;60:613-620.

43 Cookson J, Gilaberte I, Desaiah D, Kajdasz DK: Treatment benefits of duloxetine in major depressive disorder as assessed by number needed to treat. Int Clin Psychopharmacol 2006;21:267-273.

44 Hirschfeld RM, Mallinckrodt C, Lee TC, Detke MJ: Time course of depression-symptom improvement during treatment with duloxetine. Depress Anxiety 2005;21:170177.

45 Brannan SK, Mallinckrodt CH, Detke MJ, Watkin JG, Tollefson GD: Onset of action for duloxetine $60 \mathrm{mg}$ once daily: double-blind, placebo-controlled studies. J Psychiatr Res 2005;39:161-172.

46 Dunner DL, Goldstein DJ, Mallinckrodt C, Lu Y, Detke MJ: Duloxetine in treatment of anxiety symptoms associated with depression. Depress Anxiety 2003;18:53-61.

47 Beebe FA: Publication planning. Med Mark Media 2004;39:40-46.
48 Fava GA: The decline of pharmaceutical psychiatry and the increasing role of psychological medicine. Psychother Psychosom 2009; 78:220-227.

49 Jureidini JN, McHenry LB: Key opinion leaders and paediatric antidepressant overprescribing. Psychother Psychosom 2009;78: 197-201.

50 Goldstein DJ, Lu Y, Detke MJ, Wiltse C, Mallinckrodt C, Demitrack MA: Duloxetine in the treatment of depression: a doubleblind placebo-controlled comparison with paroxetine. J Clin Psychopharmacol 2004; 24:389-399.

51 Detke MJ, Lu Y, Goldstein DJ, McNamara RK, Demitrack MA: Duloxetine $60 \mathrm{mg}$ once daily dosing versus placebo in the acute treatment of major depression. J Psychiatr Res 2002;36:383-390.

52 Brannan SK, Mallinckrodt CH, Brown EB Wohlreich MM, Watkin JG, Schatzberg AF: Duloxetine $60 \mathrm{mg}$ once-daily in the treatment of painful physical symptoms in patients with major depressive disorder. J Psychiatr Res 2005;39:43-53.

53 Detke MJ, Lu Y, Goldstein DJ, Hayes JR, Demitrack MA: Duloxetine, $60 \mathrm{mg}$ once daily, for major depressive disorder: a randomized double-blind placebo-controlled trial. J Clin Psychiatry 2002;63:308-315.

54 Goldstein DJ, Mallinckrodt C, Lu Y, Demitrack MA: Duloxetine in the treatment of major depressive disorder: a double-blind clinical trial. J Clin Psychiatry 2002;63:225231.

55 Ballesteros J, Callado LF, Gutierrez M: An independent meta-analysis using summary data for clinical response, remission, and discontinuation for any reason from the 6 pivotal phase III randomized clinical trials of duloxetine in major depressive disorder. J Clin Psychopharmacol 2007;27:219-221.

56 Perahia DG, Wang F, Mallinckrodt $\mathrm{CH}$ Walker DJ, Detke MJ: Duloxetine in the treatment of major depressive disorder: a placebo- and paroxetine-controlled trial. Eur Psychiatry 2006;21:367-378.

57 Detke MJ, Wiltse CG, Mallinckrodt CH, McNamara RK, Demitrack MA, Bitter I: Duloxetine in the acute and long-term treatment of major depressive disorder: a placebo- and paroxetine-controlled trial. Eur Neuropsychopharmacol 2004;14:457-470.

58 Wise TN, Wiltse CG, Iosifescu DV, Sheridan $\mathrm{M}, \mathrm{Xu}$ JY, Raskin J: The safety and tolerability of duloxetine in depressed elderly patients with and without medical comorbidity. Int J Clin Pract 2007;61:1283-1293.

59 Eckert L, Lançon C: Duloxetine compared with fluoxetine and venlafaxine: use of metaregression analysis for indirect comparisons. BMC Psychiatry 2006;6:30
60 Fava M, Mallinckrodt CH, Detke MJ, Watkin JG, Wohlreich MM: The effect of duloxetine on painful physical symptoms in depressed patients: do improvements in these symptoms result in higher remission rates? J Clin Psychiatry 2004;65:521-530.

61 Fava M, Martinez JM, Greist J, Marangell LB, Brown E, Chen L, Wohlreich MM: The efficacy and tolerability of duloxetine in the treatment of anxious versus non-anxious depression: a post-hoc analysis of an open-label outpatient study. Ann Clin Psychiatry 2007; 19:187-195

62 Gahimer J, Wernicke J, Yalcin I, Ossanna MJ, Wulster-Radcliffe M, Viktrup L: A retrospective pooled analysis of duloxetine safety in 23,983 subjects. Curr Med Res Opin 2007; 23:175-184.

63 Goldstein DJ, Lu Y, Detke MJ, Hudson J, Iyengar S, Demitrack MA: Effects of duloxetine on painful physical symptoms associated with depression. Psychosomatics 2004; 45:17-28.

64 Hudson JI, Wohlreich MM, Kajdasz DK, Mallinckrodt CH, Watkin JG, Martynov OV: Safety and tolerability of duloxetine in the treatment of major depressive disorder: analysis of pooled data from eight placebocontrolled clinical trials. Hum Psychopharmacol 2005;20:327-341.

65 Khan A, Schwartz K: Suicide risk and symptom reduction in patients assigned to placebo in duloxetine and escitalopram clinical trials: analysis of the FDA summary basis of approval reports. Ann Clin Psychiatry 2007; 19:31-36.

66 Mallinckrodt CH, Goldstein DJ, Detke MJ, Lu Y, Watkin JG, Tran PV: Duloxetine: a new treatment for the emotional and physical symptoms of depression. Prim Care Companion J Clin Psychiatry 2003;5:19-28.

67 Mallinckrodt $\mathrm{CH}$, Raskin J, Wohlreich MM, Watkin JG, Detke MJ: The efficacy of duloxetine: a comprehensive summary of results from MMRM and LOCF_ANCOVA in eight clinical trials. BMC Psychiatry 2004;4:26.

68 Mallinckrodt $\mathrm{CH}$, Meyers AL, Prakash A, Faries DE, Detke MJ: Simple options for improving signal detection in antidepressant clinical trials. Psychopharmacol Bull 2007; 40:101-114

69 Raskin J, Wiltse CG, Siegal A, Sheikh J, Xu J, Dinkel JJ, Rotz BT, Mohs RC: Efficacy of duloxetine on cognition, depression, and pain in elderly patients with major depressive disorder: an 8-week, double-blind, placebocontrolled trial. Am J Psychiatry 2007; 164: 900-909.

70 Pigott TA, Prakash A, Arnold LM, Aaronson ST, Mallinckrodt $\mathrm{CH}$, Wohlreich MM: Duloxetine versus escitalopram and placebo: an 8-month, double-blind trial in patients with major depressive disorder. Curr Med Res Opin 2007;23:1303-1318. 
71 Nelson C, Pritchett YL, Martynov O, Yu JY, Mallinckrodt CH, Detke MJ: The safety and tolerability of duloxetine compared with paroxetine and placebo: a pooled analysis of 4 clinical trials. Prim Care Companion J Clin Psychiatry 2006;8:212-219.

72 Perahia DG, Pritchett YL, Kajdasz DK, Bauer M, Jain R, Russell JM, Walker DJ, Spencer KA, Froud DM, Raskin J, Thase ME: A randomized, double-blind comparison of duloxetine and venlafaxine in the treatment of patients with major depressive disorder. J Psychiatr Res 2008;42:22-34.

73 Raskin J, Xu JY, Kajdasz DK: Time to response for duloxetine $60 \mathrm{mg}$ once daily versus placebo in elderly patients with major depressive disorder. Int Psychogeriatr 2008;20: 309-327.
74 Nierenberg AA, Greist JH, Mallinckrodt $\mathrm{CH}$, Prakash A, Sambunaris A, Tollefson GD, Wohlreich MM: Duloxetine versus escitalopram and placebo in the treatment of patients with major depressive disorder: onset of antidepressant action, a non-inferiority study. Curr Med Res Opin 2007;23:401-416.

75 Papakostas GI, Worthington JJ, Iosifescu DV, Kinrys G, Burns AM, Fisher LB, Homberger $\mathrm{CH}$, Mischoulon D, Fava M: The combination of duloxetine and bupropion for treatment-resistant major depressive disorder. Depress Anxiety 2006;23:178-181.

76 van Baardewijk M, Vis PM, Einarson TR Cost effectiveness of duloxetine compared with venlafaxine-XR in the treatment of major depressive disorder. Curr Med Res Opin 2005;21:1271-1279.

77 Vis PM, van Baardewijk M, Einarson TR: Duloxetine and venlafaxine-XR in the treatment of major depressive disorder: a metaanalysis of randomized clinical trials. Ann Pharmacother 2005;39:1798-1807.
78 Perahia DG, Gilaberte I, Wang F, Wiltse CG, Huckins SA, Clemens JW, Montgomery SA, Montejo AL, Detke MJ: Duloxetine in the prevention of relapse of major depressive disorder: double-blind placebo-controlled study. Br J Psychiatry 2006;188:346-353.

79 Raskin J, Goldstein DJ, Mallinckrodt CH, Ferguson MB: Duloxetine in the long-term treatment of major depressive disorder. J Clin Psychiatry 2003;64:1237-1244.

80 Eli Lilly Study 4091a Summary. http://www. clinicalstudyresults.org/drugdetails/ ?unique_id=4091a\&sort=c.company_ name\&page $=1 \&$ drug_id $=170$.

81 Eli Lilly Study 3327b Summary. http://www. clinicalstudyresults.org/drugdetails/ ?unique_id $=3327 \mathrm{~b} \&$ sort $=$ c.company_ name\&page $=1 \&$ drug_id $=138$. 